\section{Jaw of the Ape-Man Paranthropus crassidens}

Dr. Robert Broom, of the Transvaal Museum, Pretoria, who is now on a visit to Great Britain, during which he has received the Wollaston Medal of the Geolgsical Society of London awarded to him this yegr, writes as follows:

"Ip N' November 1948, we found at Swartkrans while excavating a new site in co-operation with the California University Expedition a lower jaw with very large molar teeth. I called it Paranthropus crassidens. Not only did we find the imperfect jaw of a young male with three upper teeth, but also some months later the snout of what appeared to be a female. The upper incisors and canine are typically physical properties of propellants and plastics, together with studies on nitrocellulose, for the Ministry of Supply. This work included the use of $\mathrm{X}$-ray diffraction technique to follow the changes in nitrocellulose structure in cordite manufacture. In 1946 he joined the Building Research Station of the Department of Scientific and Industrial Research to set up a Rheology Section for building materials, and he has since then published several papers on the rheology of pastes as well as two books on crystals and colloids.

Although the gelatine and glue industry is relatively small, its products are essential in many industries connected with food, photography, pharmacy and many household articles, and its byproducts are fertilizers and fats. The industry has been founded on cheap raw materials such as hide waste and bones, and little change has taken place in traditional methods. Of late, production has expanded to meet all home needs and to capture export markets; but increased technical efficiency and new ideas are greatly needed if this activity is to be maintainod. It was decided, therefore, in 1947 to form a Research Association. Preliminary work was done by the Federation of Gelatine and Glue Manu. facturers, and already more than half the member firms have joined. The Research Association will work along the normal co-operative lines and will be assisted by a grant from the Department of Seientific and Industrial Research. Since the industry is not centred on any particular locality of Great Britain, the research laboratories will be set up in London. Work will be done in two main fields :

human. Last month, while I was in America, my assistant, Mr. John T. Robinson, discovered an almost complete huge jaw with most of the teeth. I have, of course, not yet seen the specimen, but the accompanying drawings were made from photo. graphs taken by Mr. Robinson. The jaw is really enormous-very considerably larger than that of Heidelberg man. The molar teeth are very large, but the canines and incisors remarkably small. Another remarkable feature about the jaw is that it has a rudiment of a chin. The ascending ramus is very high and large. Mr. Robinson has also got a part of the face with the nearly complete palate. This shows that the face is almost orthognathous. We must, I think, conclude that the brain was very large. It seems improbable that the brain can have been less than 800 c.c., and very likely it may have been more than 900 c.c. Mr. Robinson has just written me that he has part of a mandible with one molar tooth that looks remarkably human. While I can express no definite opinion until I see the specimen, it may be that the jaw is that of a small female of the same species as the large jaw."

\section{British Gelatine and Glue Research Association}

MR. A. G. W ARD has been appointed director of the newly formed British Gelatine and Glue Research Associat on. Mr. Ward's main interests have been in collon science; in particular, the relation of colloidal stucture to mechanical properties. During the War he was engaged on research on the mechanical and fundamental research on raw materials and problems affecting the industry; and research with immediate practical application, including the possibility of new uses.

\section{Italian National Awards : Einaudi Prizes}

THRovGH the/generosity of Signor Luigi Einaudi, President of thatian Republic, the Lincei Academy at Rom joward four national prizes of a million lire each at the end of every year of his term of office. The names of the first prize-winners have just been announced, as follows: General Prize (Niathematical and Natural Sciences): Prof. O. Mi. Olivo, of the University of Bologna, for researehes in bio-electric phenomena of the cardiac cell; Prize for Physics : Prof. G. P. S. Occhialini, of the University of Brussels, for researches in nuclear physics and in particular for his work on the discovery of the heavy meson; General Prize (Mioral Sciences) : Prof. R. Niondolfo, of Bologna, for work on the history of philosophy; Prize for Archæology : Prof. C. Anti, of the University of Padua, for researches on ancient Greek theatres.

\section{Science Service, Washington}

Ar the recent annual general meeting of Science Service, Dr L. A. Maynard, professor of nutrition and biochemistry of Cornell University, and Dr. Reno J. Dubos, bacteriologist and member of the Rockefeller Institute for Medical Research, New York City, were elected new trustees, being nominated 
by the National Academy of Sciences and the National Research Council, respectively. At the same time, the following officers were re-elected: President, Dr. Harlow Shapley, director of Harvard College Observatory; Vice-President and Chairman of the Executive Committee, Dr. Alexander Wetmore, secretary of the Smithsonian Institution ; Treasurer, O. W. Riegel, director of Lee School of Journalism, Washington and Lee University; Secretary, Watson Davis, director of Science Service. Additional members elected to the Executive Committee were Frank R. Ford, editor, Evansville Press, Evansville, Ind., and Dr. Karl Lark-Horovitz, Purdue University. Science Service is an endowed, non-profit-making institution for the popularization of science. The board of trustees consists of three representatives each from the American Association for the Advancement of Science, the National Academy of Sciences, the National Research Council, the journalistic profession, and the Scripps Estate. The address of Science Service is 1719 N St., N.W., Washington 6, D.C.

\section{An Unusual Solar Halo}

Mr. J. E. Bowman, Armament Research Establishment, Foft Halstead, Kent, writes : "On Niay 10 at Shoebur ness I observed a solar halo of an unusual size. Fof about the last hour before sunset a welldefined parhelion of the $22^{\circ}$ halo was visible to the north of the sun; but there was no trace of the $22^{\circ}$ halo itself. Just after the sun had set, however, the upper part of the $22^{\circ}$ halo appeared, accompanied by a much smaller halo, the radius of which I estimated to be about $8-9^{\circ}$, and a sun pillar extending to some $15^{\circ}$ above the sun. A patch of relatively greater brightness appeared where the sun pillar intersected the $8^{\circ}$ halo. The whole spectacle, which lasted until a quarter of an hour after sunset, was extremely faint and could be distinguished only with difficulty. The display of halo phenomena continued after dark, for at 10 p.m. the moon was accompanied by the two paraselenæ of the $22^{\circ}$ halo. Again, however, there was no trace of the $22^{\circ}$ halo itself.'

\section{Co-operation between Universities and Technical Colleges}

Is his address to a recent meeting of the Yorkshire Council for Furthenducation, Sir Ronald Weeks, chairman of the National Advisory Council for Education frifustry and Commerce, discussed the need formich closer co-operation between universities and technical colleges (Tech. J., 41, No. 4; Ap 1 1949). Considering the place of the graduate in industry, Sir Ronald said that more attention should be given to the possibility of strengthening the science graduate on the technological side, and the Higher National Certificate student on the science side. Arrangements should also be made whereby graduate students could attend special courses of technology at the technical college either by block release or part-time study. Sir Ronald Weeks suggested certain principles for the provision of arrangements of this kind which must be observed. Among these are the following: both universities and technical colleges must be considered available for meeting the needs, having regard to their present facilities or possible future facilities; the convenience and needs of the students must come first, particularly in the case of part-time students ; technical colleges must not be regarded as the poor relations of the universities, as this is fatal to co-operation and good understanding; there must be an easy means of transfer of students from universities to technical colleges, and vice versa.

\section{Earthquakes during March}

At least elevennotong earthquakes occurred in the world during Nirch. The greatest, and also the deepesty hasened on March 4 from a focus having an spictntre near lat. $36 \cdot 5^{\circ} \mathrm{N}$., long. $70 \cdot 5^{\circ} \mathrm{E}$., in the H rdu Kush, Afghanistan. The depth of focus was probably rather greater than $200 \mathrm{~km}$. and the strength $7 \frac{1}{2}$ on the instrumental scale. Owing to its strength and depth, the shock was felt over a wide area in Afghanistan and the North-West Frontier Province, Pakistan, and although the full extent of the damage is not yet assessed, the earthquake is known to have damaged the Roman Catholic cathedral in Lahore. The next most intense (scale $c$. 7) was probably that occurring on March 27 from a focus having an epicentre in the Celebes Sea off the southern coast of Cape Mindanoa. Strong shocks on March 16 and 17 had their epicentres in the region of the Bismarck Archipelago. On March 9 an earthquake with strength $5 \frac{1}{2}$ and epicentre near lat. $37 \cdot 1^{\circ} \mathrm{S}$., long. $121 \cdot 3^{\circ} \mathrm{W}$., in central California set off burglar alarms and rolled. stones off Telegraph Hill, San Francisco, but did no serious damage. At Hollister some windows and plaster were cracked, and small objects were shaken off shelves. Of the small shocks during the month, three may be mentioned. On March 7 an earthquake was felt with strength 3-4 on the Modified Miercalli scale in the south-west Alps near Messtetten. It had a depth of focus, according to Dr. W. Hiller, of Stuttgart, of less than $5 \mathrm{~km}$. On March 11 a strong tremor shook the area around Dalton, New South Wales, Australia, and cracked buildings there, causing damage estimated at $£ 2,000$. The shock was felt in Sydney and Canberra. On March 22 an earthquake was felt in the Département des Basses-Alpes, France, doing some damage at Lauzet. Instrumental readings for the month have been received from the central stations of the United States Coast and Geodetic Survey in co-operation with Science Service and the Jesuit Seismological Association; the Central Seismological Bureau at Strasbourg; and individual observatories at De Bilt (Netherlands), Durham, Stuttgart and Toledo.

\section{Tellus : A New Journal of Geophysics}

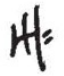

THE Second World War has brought losses and also gains in the ppiracal literature of geophysics. Among the gails Tellus, a quarterly journal of geophysics ifsued by the Swedish Geophysical Society. CVol. 1, No. 1, February 1949, consists of 64 pages, and is obtainable from the Department of Mefperplogy, University of Stockholm, price 2 U.S. doNars. The Society was founded in 1920 to promote research and international collaboration in geophysies; but the institution of a regular journal is a new departure made possible by a Government grant and by the co-operation of the Lithographic Institution of the General Staff. Contributions, to be printed in English, French or German, are invited on all branches of geophysics, from all countries. The first issue, however, is practically an all-Swedish one, the authors concerned being Pettersson, Rydbeck and Stranz, Palmén, Bergeron, Nyberg, Rossby, Ahlmann, and Ångström. Five of the contributions are meteorological; one is ionospheric, being on the 